\title{
PENGARUH SPIRITUALITAS, INTELEKTUALITAS, DAN PROFESIONALISME TERHADAP KINERJA DOSEN STAIN SALATIGA
}

\author{
Abdul Aziz Nugraha Pratama \\ Sekolah Tinggi Agama Islam Negeri (STAIN) Salatiga \\ pratama_abdul@yaboo.com
}

\begin{abstract}
This study aims to determine the effect of each variable spirituality, intellect, and professionalism of the lecturers performance STAIN Salatiga. The population of this study are all tenured State Institute of Islamic Studies (STAIN) Salatiga as many as 107 people. The sampling technique used in this study using simple random sampling and 65 were taken as respondents. With quantitative methods and analysis techniques that use moderated regression analysis (MRA), it can be concluded that (1) spirituality is partially not significantly affect the performance of the faculty; (2) the partial intellect does not significantly affect the performance of the faculty; (3) professionalism partially positive and significant effect on the performance of the lecturer. (4) spirituality, intellect and professionalism of lecturers jointly affect the performance of the lecturer. The study also found that the majority of respondents aged very productive, but they are staying at very far away from the campus.
\end{abstract}

Keywords: Sprituality, Intelectualitys, Professionalisme, Performance

\begin{abstract}
Abstrak
Penelitian ini bertujuan untuk mengetabui pengarub masing-masing variabel Spiritualitas, Intelektualitas, dan Profesionalisme terhadap Kinerja Dosen STAIN Salatiga. Populasi penelitian ini adalab selurub dosen tetap Sekolab Tinggi Agama Islam Negeri (STAIN) Salatiga sebanyak 107 orang. Teknik sampling yang digunakan dalam penelitian ini menggunakan Simple Random Sampling dan diambil 65 sebagai responden. Dengan metode kuantitatif dan teknik analisis yang menggunakan moderated regression analysis (MRA), maka dapat disimpulkan babwa (1) spiritualitas secara parsial tidak berpengarub secara signifikan terhadap kinerja para dosen; (2) intelektualitas secara parsial tidak berpengarub secara signifikan terhadap kinerja para dosen; (3) profesionalisme secara parsial berpengarub positif dan signifikan terhadap kinerja dosen. (4) Spiritualitas, intelektualitas dan profesionalisme dosen secara bersama-sama berpengarub terbadap kinerja dosen. Penelitian ini juga menemukan babwa responden mayoritas berusia sangat produktif, namun bertempat tingal tinggal sangat jaub dari kampus
\end{abstract}

Kata Kunci: Spritualitas, Intelektualitas, Profesional, Performa 


\section{Pendahuluan}

Beberapa dekade terakhir ini menunjukkan bahwa perusahaan besar kelas dunia yang melaksanakan pelatihan spiritual bagi pegawainya. Lebih hebat lagi, pegawai yang ditraining spiritualitas ini bukan hanya jajaran tertentu, namun semua jajaran, dari tingkat eksekutif, manajemen staf hingga operator lapangan.

Berbagai perusahaan dunia telah memberikan pelatihan spiritualitas kepada karyawannya. Demikian pula di Indonesia, seperti yang terjadi di ESQ Leadership Center, berbagai perusahaan terkemuka telah mengirimkan para eksekutifnya untuk mengikuti berbagai pelatihan spiritual yang diselenggarakan oleh institusi tersebut. Garuda Indonesia, sebagai misal, telah mengirimkan bukan hanya eksekutifnya, namun juga pilot-pilotnya. Lebih hebat lagi, perusahaan pabrik baja terbesar di Asia Tenggara, PT Krakatau Steel mewajibkan seluruh jajaran manajemen staf hingga operator lapangannya yang berjumlah 6.000 orang untuk mengikuti pelatihan spiritual ESQ. Begitu pula Pertamina Balongan dan Pertamina Cirebon, PT Pusri, Taspen, dan berbagai perusahaan besar lainnya, (Irmim dan Rochim,2006: iv).

Sekolah Tinggi Agama Islam Negeri SalatigaatauSTAIN Salatigaadalah Perguruan Tinggi Agama Islam Negeri di Salatiga provinsi Jawa Tengah, Indonesia. STAIN Salatiga didirikan berdasarkan pada Surat Keputusan Presiden Nomor 11 Tanggal 21 Maret 1997 bertepatan dengan Tanggal 12 Dzulqaidah 1417 H. (Wikipedia bttp://id.wikipedia.org/wiki/STAIN_Salatiga).

Sudah beberapa tahun, kampus ini memiliki slogan: "Membangun spiritualitas, intelektualitas, dan profesionalisme". Slogan tersebut tercantum di website STAIN Salatiga dan tempat-tempat lain. Namun belum banyak civitas akademika STAIN Salatiga yang merasakan secara khusus kehadiran slogan tersebut. Apalagi jika slogan atau motto tersebut dijadikan acuan pengelolaan lembaga pendidikan tinggi Islam satu-satunya di Salatiga tersebut. Seharusnya, slogan tersebut menjadi tolak ukur pengelolaan lembaga milik Negara tersebut.

Di tengah dinamika pengelolaan sebuah lembaga atau organisasi memang harus diupayakan agar dapat diukur perkemba- 
ngannya secara periodik. Dengan demikian akan diketahui tingkat kemajuan atau pun kemundurannya. Atau dengan kata lain, pengelolaan organisasi atau lembaga harus berbasis kinerja yang terukur.

Kinerja pada dasarnya merupakan hasil kerja secara kualitas dan kuantitas yang dicapai seorang pegawai dalam melaksanakan tugasnya sesuai tanggung jawab yang diberikan kepadanya. Dalam hal ini, pegawai bisa belajar seberapa besar kinerja mereka melalui sarana informasi seperti komentar baik dari mitra kerja. Namun demikian penilaian kinerja yang mengacu kepada suatu sistem formal dan terstruktur yang mengukur, menilai dan mempengaruhi sifatsifat yang berkaitan dengan pekerjaan perilaku dan hasil termasuk tingkat ketidakhadiran.

Penelitian ini hendak mencoba mengkaji bagaimana tingkat keberhasilan STAIN Salatiga membangun spiritualitas, intelektualitas, profesionalisme dalam mencapai kinerja yang ideal. Di samping itu juga untuk menemukan berbagai gap research dalam Manajemen sumberdaya manusia.

Secara khusus, penelitian ini ingin menjawab pertantaanpertanyaan tentang seberapa tinggi tingkat spiritualitas, intelektualitas, profesionalisme, dan kinerja dosen STAIN Salatiga, serta bagaimana pengaruh intelektualitas terhadap kinerja dosen STAIN Salatiga

\section{Spiritualitas}

Istilah spiritual merujuk pada nilai dan makna dasar yang melandasi hidup kita, baik duniawi maupun ukhrawi, entah secara sadar atau tidak meningkatkan komitmen kita terhadap nilai-nilai dan makna tersebut. Istilah spiritualitas memang memiliki konotasi nilai-nilai religius dalam arti bahwa nilai dan makna dasar yang dimiliki seseorang mencerminkan hal-hal yang dianggapnya suci, yaitu yang memiliki kepentingan yang paling mendasar (Griffin, 2005:15).

Spiritualitas dalam pengertian yang umum adalah disposisi mental dan komitmen personal yang dibentuk oleh konstelasi nilai dan makna, produk dan gambaran dunia tertentu (Griffin, 2005). Spiritualitas dalam pembicaraan ini berkaitan dengan kehakikian dan keabadian serta ruh, bukan sesuatu yang bersifat temporal dan elastis. Spiritualitas yang bersumber dari jantung ajaran agama- 
agama besar, berkaitan langsung dengan kesadaran ketuhanan.

Kesadaran ketuhanan sebagai inti dari spiritualitas ini merupakan modal dasar yang dimiliki oleh setiap orang yang diharapkan dapat mewarnai segala aktifitas kehidupannya. Dalam konteks perilaku bisnis, spiritualitas memberikan wawasan dan pemahaman bahwa bisnis yang dilakukan seseorang berhubungan erat dengan realitas material dan spiritual secara bersamaan. Dengan pemahaman ini, maka asumsi-asumsi sempit yang menempatkan manusia (pelaku bisnis) sebagai makhluk ekonomi yang mementingkan kepentingan diri sendiri dengan orientasi keuntungan material sebagai fokus utama tidak dapat dibenarkan dan tidak sejalan dengan fakta-fakta yang ditemukan saat ini.

Dalam pembahasan spiritualitas dikenal adanya dimensi spiritualitas. Terdapat sembilan dimensi spiritualitas, yaitu:

a. Dimensi transenden (Transcendent dimension)

Inti dari keyakinan ini berupa kepercayaan terhadap Tuhan atau apapun yang dipersepsikan oleh individu sebagai sosok transenden ataupun sesuatu yang lebih besar dari diri seorang individu (Santosa, 2011).

b. Makna dan tujuan dalam hidup (Meaning and purpose in life) Memahami proses pencarian akan makna dan tujuan hidup yang memunculkan hidup yang lebih bermakna dan mencapai tujuan (Santosa, 2011)

c. Misi hidup (Mission in life)

Adanya panggilan yang harus dipenuhi, rasa tanggung jawab pada kehidupan, panggilan untuk menjawab, menyelesaikan misi, atau dibeberapa kasus dalam memenuhi takdir. (Santosa, 2011).

d. Kesakralan hidup (Sacredness of life)

Pandangan akan hidup tidak lagi dikotomi seperti pemisahan antara yang sakral dan yang sekuler, suci dan duniawi, namun percaya bahwa semua aspek kehidupan sifatnya suci dan kesakralan ada di dalamnya (Santosa, 2011).

e. Nilai-nilai material (Material values)

Kepuasaan dalam hidup datang bukan dari seberapa banyak kekayaan yang dimiliki, namun dari hal spiritual. 


\section{f. Altruisme (Altruism)}

Adanya tanggung jawab bersama dari masing-masing orang untuk saling menjaga sesama (brother's keepers), baik dari rasa sakit dan penderitaan (Santosa, 2011).

g. Idealisme (Idealism)

Orang yang spiritual berkomitmen terhadap sikap ideal yang tinggi dan mengaktualisasikannya melalui potensi positif dalam semua aspek kehidupannya (Santosa, 2011).

h. Kesadaran akan peristiwa tragis (Awareness of the tragic)

Menyadari dengan sungguh-sungguh bahwa tragedi terjadi dalam eksistensi manusia. Peduli terhadap rasa sakit, penderitaan atau kematian (Mulyana, 2006).

i. Manfaat (Beneficial manifestations (fruit of spirituality)

Individu menilai spiritualitas merupakan buah dari kehidupan (Mulyana, 2006).

Sebagaimana diketahui bahwa tujuan spiritualitas adalah meraih kondisi diri yang berkembang atau mencapai potensi tertinggi yang pada gilirannya akan membawa individu pada kreativitas, motivasi, dan komitmen organisasi (Neck \& Milliman, 1994). Penelitian-penelitian tentang spiritualitas dikaitkan dengan kinerja bahwa motivasi spiritual memberikan pengaruh secara langsung yang positif signifikan terhadap kinerjakaryawan (Permana, 2012).

Dengan demikian, hipotesisnya adalah sebagai berikut :

H1. Spiritualitas berpengaruh positif terhadap kinerja dosen STAIN Salatiga

\section{Intelektualitas}

Pengertian intelektualitas, dapat dikutip dari M. Rusli Karim memberikan kriteria intelektual muslim dengan memandang berbagai segi, yaitu (Karim, 2013: 112): 1). Dilihat dari latar belakang pendidikan, minimal pernah mengikuti kuliah di Perguruan tinggi sampai dengan yang bergelar doktor.; 2). Jauh dekatnya dengan umat Islam. Karena memiliki integritas yang mencerminkan nilainilai dan ajaran Islam serta berpihak pada Islam; 3). Dari segi 
aktivitasnya yang mencerminkan kepentingan umat Islam: a) Sering diundang untuk berceramah/khutbah mulai dari tingkat terendah sampai tingkat nasional b) Sering terlibat/diikutkan dalam kegiatan diskusi, lokakarya dan seminar tentang Islam c) Banyak menaruh perhatian terhadap perkembangan pemikiran Islam d) Pernah menulis tentang Islam; 4). Menjadi sumber panutan (Resources Person) di lingkungannya; 5). Terlibat dalam lembaga (swasta atau pemerintah atau komunitas tertentu). 6). Memiliki concern dan komitmen yang kuat terhadap nilai-nilai dan ajaran Islam yang terpancar dalam pemikiran, sikap dan tingkah laku sehari-hari secara terus menerus.

Menurut Jalaluddin Rahmat, kaum intelektual adalah kelompok orang yang merasa terpanggil untuk memperbaiki masyarakatnya dan menangkap aspirasi mereka, merumuskan dalam bahasa yang dapat dipahami setiap orang dengan menawarkan strategi dan alternatif pemecahan masalah (Rahmat, 1991:211-212).

Dari pernyataan tersebut di atas, dapatlah diambil suatu pengertian bahwa intelektual muslim bukan hanya sekedar orang yang mengadakan berbagai penelitian dan penalaran, tetapi cendekiawan muslim adalah seorang yang di samping berpendidikan tinggi dan berusaha untuk mendalami berbagai disiplin ilmu, mereka juga merasa terpanggil untuk memperbaiki masyarakat serta menangkap aspirasi mereka, dan merumuskannya dalam bahasa yang mudah dipahami, juga menawarkan jalan keluar untuk menyelesaikan masalah-masalah yang dihadapi masyarakat.

Hal yang membedakan antara seorang intelektual dengan non intelektual kemampuan berpikir bebas sebagai kebalikan dari kecenderungan mengikuti saja pemikiran orang lain. Konsep bebas dalam hal ini mencakup pengamatan yang cermat terhadap gejalagejala yang ada dalam suatu lingkungan dan pemahaman tentang sebab-sebab serta korelasinya dengan gejala-gejala lainnya, dan pada akhirnya merumuskan suatu kesimpulan yang dapat dikomunikasikan kepada orang lain dengan bahasa yang jelas (Rahmat, 1991: 211-212).

M. Dawam Raharjo mengonotasikan cendekiawan muslim dengan ulama, dengan menafsirkan sebuah hadits Nabi SAW yang 
mengatakan bahwa: "Ulama itu adalah pewaris Nabi". Para cendekiawan muslim dapat disebut juga sebagai pewaris para Nabi, sepanjang mereka itu berjuang untuk membawa risalah Nabi (Susanti, 2013:10).

Dari definisi tersebut dapat diambil suatu pengertian bahwa kecendekiaan seseorang ditandai sebab kedalaman ilmu yang ditekuni, serta adanya komitmen terhadap keilmuan dan perjuangan terhadap ajaran agama Islam. Dalam melaksanakan segala aktivitas tersebut, mereka mempunyai komitmen yang sangat kuat terhadap perjuangan agama Islam, sehingga mereka rela berkorban untuk kepentingan masyarakat.

Kinerja karyawan tidak hanya dilihat dari kemampuan kerja yang sempurna, tetapi juga kemampuan menguasai dan mengelola diri sendiri serta kemampuan dalam membina hubungan dengan orang lain (Martin, 2000: 22). Kemampuan tersebut oleh Daniel Goleman disebut dengan Emotional Intelligence atau kecerdasan emosi. Goleman (2000: 46) melalui penelitiannya mengatakan bahwa kecerdasan emosi menyumbang $80 \%$ dari faktor penentu kesuksesan sesorang, sedangkan $20 \%$ yang lain ditentukan oleh IQ (Intelligence Quotient).

Dengan demikian, hipotesisnya adalah sebagai berikut :

H2. Intelektual berpengaruh negatif terhadap Kinerja dosen STAIN Salatiga

\section{Profesionalisme}

Kata profesi berarti pekerjaan yang dilakukan sebagai nafkah hidup dengan mengandalkan keahlian dan keterampilan (kemahiran) yang tinggi dan dengan melibatkan komitmen pribadi (moral) yang mendalam. Profesional merupakan orang yang melakukan kegiatan atau menjalani profesi tertentu. Di samping itu, professional adalah sikap atau perilaku seseorang dalam melakukan profesi tertentu. Dalam pengertian umum, seseorang dikatakan profesional jika memenuhi tiga kriteria, yaitu mempunyai keahlian untuk melaksanakan tugas sesuai dengan bidangnya, melaksanakan tugas dengan menetapkan standar baku dalam bidangnya dan menjalankan tugas profesi yang telah ditetapkan (Husman, 2006). 
Profesioanalisme adalah mutu, kualitas dan tindak tanduk yang merupakan ciri suatu profesi atau orang yang professional. Dan menurut kamus besar bahasa Indonesia, guru adalah orang yang pekerjaannya (mata pencahariannya, profesinya) mengajar.

Adapun Indikator guru yang profesional adalah : a). Selalu membuat perencanan kongkrit dan detail yang siap untuk dilaksanakan peserta didik dalam kegiatan pembelajaran; b). Berusaha mengubah pola pikir lama menjadi pola pikir baru yang menempatkan peserta didik sebagai arsitek pembangun gagasan dan guru berfungsi untuk melayani dan berperan sebagai mitra peserta didik supaya peristiwa belajar bermakna langsung pada semua individu; c). Bersikap kritis dan berani menolak kehendak yang kurang edukatif;d). Berkehendak mengubah pola tindakan dalam meningkatkan peran peserta didik, guru berperan dan bergaya mengajar; e). Berani menyakinkan kepada sekolah, orang tua dan masyarakat agar dapat berpihak pada kepentingan peserta didik yang cenderung sulit diterima oleh orang awam dengan menggunakan argumentasi yang logis dan kritis; f). Bersikap kreatif dalam membangun dan menghasilkan karya pendidikan.

Berdasarkan uraian di atas, profesionalisme dapat diartikan sebagai pandangan tentang bidang pekerjaan yaitu pandangan yang menganggap bidang pekerjaan sebagai suatu pengabdian melalui keahlian tertentu dan yang menganggap keahlian ini sebagai suatu yang harus diperbaharui secara terus menerus dengan memanfaatkan kemajuan-kemajuan yang terdapat dalam ilmu pengetahuan.

Dalam UU Guru dan Dosen No 14 tahun 2005 ditentukan bahwa seorang pendidik wajib memiliki kualifikasi akademik dan kompetensi pendidik sebagai agen pembelajaran. Kompetensi profesi pendidik meliputi kompetensi pedagogik, kompetensi kepribadian, kompetensi profesional, dan kompetensi sosial.

a. Kompetensi pedagogik, yakni kemampuan mengelola pembelajaran peserta didik yang meliputi pemahaman terhadap peserta didik, perancangan dan pelaksanaan pembelajaran, evaluasi hasil belajar, dan pengembangan peserta didik untuk mengaktualisasikan berbagai potensi yang dimilikinya. 
b. Kompetensi kepribadian, yakni kepribadian pendidik yang mantap, stabil, dewasa, arif, dan berwibawa, menjadi teladan bagi peserta didik, dan berakhlak mulia.

c. Kompetensi social, yakni kemampuan pendidik berkomunikasi dan berinteraksi secara efektif dengan peserta didik, sesama pendidik, tenaga kependidikan, orangtua/wali peserta didik, dan masyarakat.

d. Kompetensi professional, yakni kemampuan pendidik dalam penguasaan materi pembelajaran secara luas dan mendalam yang memungkinkannya membimbing peserta didik memperoleh kompetensi yang ditetapkan. Untuk dapat menetapkan bahwa seorang pendidik sudah memenuhi standard profesional maka pendidik yang bersangkutan harus mengikuti uji sertifikasi.

Wroom (1964) mengemukakan bahwa kinerja karyawan dipengaruhi oleh profesionalisme. Apabila tuntutan kerja yang dibebankan pada individu tidak sesuai dengan kemampuannya (ability) maka kinerja yang diharapkan akan sulit tercapai. Penelitian yang dilakukan oleh Cahyasumirat (2006) menyatakan tidak adanya pengaruh yang positif antara profesionalisme dengan kinerja internal auditor. Sementara itu terdapat penelitian yang dilakukan Rahmawati (1997) dan Jantje (1999) yang menyatakan bahwa profesionalisme berhubungan positif dengan kinerja.

Dengan demikian, hipotesisnya adalah sebagai berikut :

H3. Profesionalisme berpengaruh positif terhadap kinerja dosen STAIN Salatiga

\section{Kinerja}

Kinerja adalah hasil kerja yang dapat dicapai oleh seseorang atau kelompok orang dalam suatu organisasi sesuai dengan wewenang dan tanggung jawab masing-masing dalam rangka upaya mencapai tujuan organisasi bersangkutan secara legal tidak melanggar hukum dan sesuai dengan moral maupun etika.

Kinerja juga merupakan keluaran yang dihasilkan oleh fungsifungsi atau indikator suatu pekerjaan atau suatu profesi dalam waktu tertentu (Wirawan,2009: 5). Kamus besar bahasa Indonesia (2008: 
629) mendefinisikan karyawan adalah orang yang bekerja pada suatu lembaga (kantor, perusahaan, dan sebagainya) dengan mendapat gaji atau upah.

Menurut Richard I. Handerson (1984) dalam Wirawan (2009: 53) dimensi kinerja adalah kualitas-kualitas atau wajah suatu pekerjaan atau aktivitas-aktivas yang terjadi di tempat kerja yang konduktif terhadap pengukuran". Dimensi kinerja menyediakan alat untuk melukiskan keseluruhan cakupan aktivitas di tempat kerja. Sementara itu, tanggung jawab dan kewajiban menyediakan suatu deskripsi depersonalisasi.

Indikator-indikator kinerja karyawan menurut Chester I. Barnard dan Robert E. Quinn dalam Suyadi Prawirosentono (2008:27-32) adalah sebagai berikut: 1) Efektivitas dan efisiensi. Bila suatu tujuan tertentu akhirnya dapat dicapai, kita boleh mengatakan bahwa kegiatan tersebut efektif.; 2) Otoritas dan tanggung jawab; Wewenang adalah hak seseorang untuk memberikan perintah (kepada bawahan), sedangkan tanggung jawab adalah bagian yang tidak terpisahkan atau sebagai akibat dari kepemilikan wewenang tersebut.; 3) Disiplin. Disiplin meliputi ketaatan dan hormat terhadap perjanjian yang dibuat antara perusahaan atau organisasi dan karyawan.; 4) Inisiatif. Inisiatif seseorang berkaitan dengan daya pikir, kreativitas dalam bentuk ide untuk merencanakan sesuatu yang berkaitan dengan tujuan organisasi. Berdasarkan pendapat di atas, kinerja adalah kesediaan seseorang atau kelompok orang untuk melakukan sesuatu kegiatan dan menyempurnakannya sesuai dengan tanggung jawabnya dengan hasil seperti yang diharapkan.

\section{Kerangka Teoritis}

Berdasarkan tinjauan pustaka dan beberapa dasar teori yang ada, maka berikut ini dibentuk kerangka pemikiran: 


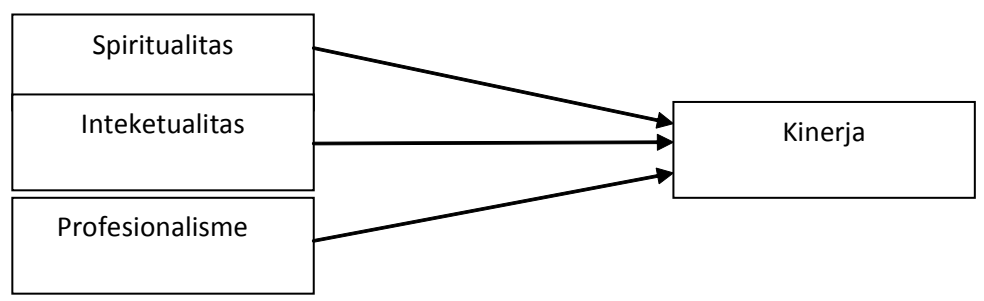

Gambar 1. Kerangka Teoritis

\section{Metode Penelitian}

\section{Obyek Penelitian}

Seluruh dosen PNS di STAIN Salatiga menjadi obyek dalam penelitian ini.

\section{Populasi dan Sampel}

Populasi penelitian ini adalah semua dosen STAIN Salatiga. Sedangkan sampel ditentukan dengan menggunakan Simple Random Sampling, yakni sampel diambil secara acak, tanpa memperhatikan tingkatan yang ada dalam populasi. Populasi penelitian ini adalah seluruh dosen STAIN Salatiga tahun 2013 yang berjumlah 107 orang.

Penentuan jumlah sampel dengan menggunakan rumus (Bawono, 2006):

$$
\mathrm{S}=\frac{P}{\left(P * \alpha^{2}\right)+1}
$$

Di mana:

$$
\mathrm{S}=\text { Jumlah Sampel }
$$

$\mathrm{P}=$ Jumlah Populasi

$\alpha=$ Taraf keyakinan kesalahan (signifikansi: 8\%)

Dengan demikian, jika jumlah populasi sebanyak 107 dan tingkat kesalahan yang dikehendaki 8\%, maka jumlah sampel yang digunakan adalah : 
$S=\frac{107}{\left(107 * 0,08^{2}\right)+1}$

$S=63,509$

Berdasarkan perhitungan tersebut di atas, maka jumlah sampel yang harus digunakan dibulatkan menjadi 65. Dalam penelitian ini jumlah sampel di ambil sebanyak 65 yang diambil secara acak tanpa memperhatikan pangkat, usia dan jenis kelamin.

\section{Pengukuran Data}

\section{Sumber Data}

Data yang digunakan dalam penelitian ini adalah data primer dan sekunder.

\section{Metode Pengumpulan data}

Pengumpulan data dilakukan dengan penyebaran kuesioner pada responden penelitian.

\section{Uji Instrumen Penelitian}

Uji instrumen yang digunakan dalam penelitian ini meliputi uji validitas dan uji reliabilitas. Menurut Sekaran (2006:332), uji validitas merupakan bukti bahwa instrumen, teknik, atau proses yang digunakan untuk mengukur sebuah konsep benar-benar mengukur konsep yang dimaksudkan. Reliabilitas adalah pengukuran yang menunjukkan sejauh mana alat ukur dapat dipercaya dan sejauh mana hasil pengukuran tetap konsisten dan karena itu menjamin pengukuran yang konsisten lintas waktu dan lintas beragam item dalam instrumen (Sekaran, 2006:40). Uji reliabilitas bertujuan untuk mengetahui tingkat konsistensi terhadap instrumen-instrumen yang mengukur konsep.

\section{Uji Asumsi Klasik}

Uji Asumsi klasik yang di lakukan meliputi uji heteroskedatisitas dan uji multikolinearitas 


\section{Metode Analisis Data}

Pengujian hipotesis dalam penelitian ini dilakukan dengan menggunakan uji analisis regresi, yaitu Moderated Regression Analysis (MRA) dengan bantuan perangkat lunak SPSS versi 16.00. Moderated Regression Analysis (MRA) atau uji interaksi merupakan aplikasi khusus regresi berganda linear di mana dalam persamaan regresinya mengandung unsur interaksi (perkalian dua atau lebih variabel independen) dengan rumus persamaan sebagai berikut:

$$
\mathrm{Y}=\alpha+\beta 1 X 1+\beta 2 X 2+\beta 3 X 3+e
$$

Keterangan :

$\mathrm{Y}=$ Kinerja dosen

$\mathrm{X} 1=$ Spiritualitas

$\mathrm{X} 2$ = Intelektualitas

$\mathrm{X} 3$ = Profesionalisme

$\alpha=$ Konstanta/intercept

$\beta=$ Koefisien regresi variabel $\mathrm{X}$

$\mathrm{e}=$ Error disturbance

\section{Gambaran Umum Responden}

Responden penelitian ini adalah khusus para dosen di STAIN Salatiga. Berdasarkan data terbaru dari Sub Bagian Kepegawaian STAIN Salatiga tahun 2013 dapat diuraikan sebagai berikut :

Tabel 1. Jumlah Dosen Tetap dan Distribusi Setiap Program Studi di STAIN Salatiga Tahun 2013

\begin{tabular}{llc}
\hline NO & \multicolumn{1}{c}{ PROGRAM STUDI } & JUMLAH DOSEN \\
\hline 1. & Pendidikan Agama Islam (PAI) & 15 \\
2. & Tadris Bahasa Inggris (TBI) & 14 \\
3. & Pendidikan Bahasa Arab (PBA) & 8 \\
4. & Pendidikan Guru Madrasah Ibtidaiyah (PGMI) & 10 \\
5. & Ahwalus Syahsiyyah (AS) & 8 \\
6. & Hukum Ekonomi Syariah (HES) & 6 \\
7. & Perbankan Syariah (PS) Strata Satu (S.1) & 10 \\
8. & Perbankan Syariah (PS) Diploma Tiga (D.III) & 6 \\
9. & Pendidikan Guru Raudhatul Athfal (PGRA) & 6 \\
10. & Sejarah Kebudayaan Islam (SKI) & 6 \\
11. & Komunikasi Penyiaran Islam (KPI) & 6 \\
12. & Ilmu Al-Qur'an dan Tafsir (IAT) & 6 \\
13. & Pasca Sarjana (S.2) PAI & 6 \\
& $\quad$ Jumlah Total & 107 \\
\hline
\end{tabular}


Total populasi, yakni seluruh dosen STAIN Salatiga adalah sebanyak 107 orang. Kuesioner yang disebarkan sejumlah 80 buah. Kuesioner yang kembali dan dapat diolah sebanyak 65 buah.

Jumlah responden yang digunakan dalam analisis sebanyak 65 responden. Secara demografis, profil responden yang berpartisipasi dalam penelitian ini diketahui bahwa dari 65 responden, sebanyak 13,84\% atau 9 responden bekerja di STAIN Salatiga selama $1-5$ tahun, 16,92\% atau 11 selama $6-10$ tahun dan 44,61\% atau 29 responden selama $11-15$ tahun, dan sebanyak 16 responden atau 24,61\% > 16 tahun. Dengan demikian, dapat dinyatakan bahwa sebagian besar responden bekerja di STAIN Salatiga antara 11-15 tahun.

Dalam hal jarak tempat tinggal diketahui bahwa dari 65 responden, sebanyak 15,39\% atau 10 responden tinggal yang berjarak $500-<1000 \mathrm{~m}$ dari kampus STAIN Salatiga, 15,39\% atau 10 responden lagi tinggal yang berjarak $1000-<1500 \mathrm{~m}, 9,23 \%$ atau 6 responden tinggal berjarak antara $1500-<2000 \mathrm{~m}$, dan sebanyak $60 \%$ atau 39 responden tinggal pada jarak $>2000 \mathrm{~m}$. Dengan demikian, dapat dinyatakan bahwa sebagian besar responden tinggal lebih jauh dari $2000 \mathrm{~m}$ dari kampus STAIN Salatiga.

Menurut hasil penelitian Isti Fadah dan Istatuk Budi Yuswanto (2004) yang berjudul "Hubungan Antara Jarak dari Tempat Tinggal Pekerja ke Tempat Kerja dengan Curahan Waktu Kerja” (dalam Widyawati dan Pujiyono, 2013:3), jarak dari tempat tinggal pekerja ke tempat kerja merupakan jarak yang harus ditempuh responden menuju tempat bekerja. Semakin jauh jaraknya maka waktu yang terbuang semakin banyak, tingkat efisiensi waktu menurun, akibatnya curahan waktu kerja akan semakin berkurang.

Menurut Mc. Charty dalam Swastha Basu (2000), jarak lokasi dikategorikan menjadi empat, yaitu : a).Sangat dekat apabila jarak lokasi tersebut $500 \mathrm{~m}-<1000 \mathrm{~m}$ dengan tempat tinggal konsumen; b) Dekat apabila jarak lokasi tersebut $1000 \mathrm{~m}-<1500 \mathrm{~m}$ dengan tempat tinggal konsumen; c) Agak jauh apabila jarak lokasi tersebut $1500 \mathrm{~m}-<2000 \mathrm{~m}$ dengan tempat tinggal konsumen; d) Jauh apabila jarak lokasi tersebut $>2000 \mathrm{~m}$ dengan tempat tinggal konsumen. 
Dengan demikian berarti mayoritas dosen STAIN Salatiga, khususnya yang menjadi responden dalam penelitian ini, tinggal yang lokasinya masuk kategori "Sangat Jauh" dari kampus STAIN Salatiga. Hal ini tentu berdampak kurang baik untuk mendukung kemajuan lembaga STAIN Salatiga. Dan tentu saja harus dicari solusi terbaik agar dosen dari lembaga Perguruan Tinggi Agama Islam Negeri satu-satunya di Kota Salatiga ini mendapatkan solusi yang saling menguntungkan.

Menurut data, dari 65 responden, sebanyak 3,08\% atau 2 responden berpendidikan terakhir $S 1,72,301 \%$ atau 47 responden berpendidikan terakhir S2, 20\% atau 13 orang berpendidikan S3 dan 4,62\% sudah mengikuti Post Doctor. Dengan demikian, dapat dinyatakan bahwa sebagian besar responden berpendidikan terakhir sarjana S2.

Juga diketahui bahwa dari 65 responden, sebanyak 70,77\% atau 46 responden adalah laki-laki dan 29,23\% atau 19 responden adalah wanita. Dengan demikian, dinyatakan bahwa sebagian besar responden berjenis kelamin laki-laki.

Berdasarkan data, diketahui bahwa dari 65 responden, yang biasa mengatur keuangan rumah tangganya sehingga hanya mengeluarkan uang kurang dari Rp. 2.500.000,- sebanyak 3,08\% atau 2 orang. Sementara itu yang memiliki pengeluaran antara Rp. 2.500.000, hingga Rp. 5.000.000,- sebanyak 17 orang atau 26,15\% dari keseluruhan responden. Adapun yang memiliki pengeluaran antara Rp. 7.600.000, s/d Rp. 10.000.000,- berjumlah 7 orang atau $10,77 \%$ dari keseluruhan responden. Sedangkan untuk pengeluaran terbesar dalam kategori di atas, yakni di atas Rp. 10.000.000,sebanyak 3 orang atau 4,62\% dari keseluruhan responden sebanyak 65 orang. Dengan demikian, dapat dinyatakan bahwa sebagian besar responden memiliki pengeluaran antara Rp. 2.500.000, hingga Rp. 5.000.000,-. Kondisi tersebut menunjukkan bahwa para dosen STAIN Salatiga sudah sangat bagus dalam mengatur keuangan rumah tangganya. Mereka dapat menyesuaikan antara penghasilan yang diterima dengan pengeluaran setiap bulannya.

Sementara itu, diketahui bahwa dari 65 responden, sebanyak 1,54\% atau 1 responden adalah dosen STAIN Salatiga yang berusia 
anatar 20 -30 tahun, 50,77\% atau 33 responden berusia antara $31-$ 40 tahun dan $32,31 \%$ atau 21 responden berusia antara $41-50$ tahun, sebanyak $12,31 \%$ atau 8 responden berusia antara $31-60$ tahun, dan sebanyak 2 responden atau 3,08\% berusia antara 61 sampai dengan 65 tahun. Dengan demikian, dapat dinyatakan bahwa sebagian besar responden adalah berusia antara 31 -40 tahun. Hal ini berarti bahwa mayoritas dosen STAIN Salatiga pada tahun 2014 mayoritas berusia produktif. Dengan kondisi demikian, lembaga ini sangat berpeluang untuk lebih maju kian pesat.

\section{Analisis}

\section{Estimasi Regresi Linear Berganda}

Hasil estimasi model regresi dengan bantuan SPSS for Windows release 16.00 disajikan pada tabel berikut :

Tabel 2. Hasil Regresi Linear Berganda

\begin{tabular}{|c|c|c|c|c|c|c|}
\hline & \multirow[t]{2}{*}{ Model } & \multicolumn{2}{|c|}{$\begin{array}{l}\text { Unstandardized } \\
\text { Coefficients }\end{array}$} & \multirow{2}{*}{$\begin{array}{c}\begin{array}{c}\text { Standardized } \\
\text { Coefficients }\end{array} \\
\text { Beta }\end{array}$} & \multirow[t]{2}{*}{$\mathrm{t}$} & \multirow[t]{2}{*}{ Sig. } \\
\hline & & $\mathrm{B}$ & Std. Error & & & \\
\hline \multirow[t]{4}{*}{1} & (Constant) & 8.096 & 3.456 & & 2.342 & .022 \\
\hline & Spirit & -.039 & .033 & -.112 & -1.189 & .239 \\
\hline & Intelek & .032 & .029 & .085 & 1.129 & .263 \\
\hline & Prof & .115 & .013 & .867 & 8.931 & .000 \\
\hline
\end{tabular}

a. Dependent Variable: Kinerja

Berdasar hasil analisis regresi linear berganda pada tabel di atas, diperoleh persamaan regresi sebagai berikut:

Kinerja $=8,096-$ 0,039 Spirit. + 0,032 intelek. + 0,115 profesional $+\mathrm{e}$

1. Konstan $=8,096$, artinya : jika besarnya nilai variabel spiritualitas besarnya sama atau konstan, maka besarnya Kinerja akan naik sebesar 8,096 satuan dengan asumsi Ceteris Paribus.

2. Koefisien Spiritualitas $=0,039$ yang artinya bahwa jika variabel spiritualitas naik 1 (satu) satuan, sedangkan intelektualitas dan profesionalisme besarnya sama dengan 0 (nol) atau konstan, maka besarnya Kinerja akan naik sebesar 0,039 satuan dengan asumsi Ceteris Paribus. 
3. Koefisien Intelektualitas $=0,032$ yang artinya bahwa jika variabel Intelektualitas naik 1 (satu) satuan, sedangkan Spiritualitas dan profesionalisme besarnya sama dengan 0 (nol) atau konstan, maka besarnya Kinerja akan naik sebesar 0,032 satuan dengan asumsi Ceteris Paribus.

4. Koefisien Profesionalisme $=0,115$ yang artinya bahwa jika variabel Profesionalisme naik 1 (satu) satuan, sedangkan Spiritualitas dan Intelektualitas besarnya sama dengan 0 (nol) atau konstan, maka besarnya Kinerja akan naik sebesar 0,115 satuan dengan asumsi Ceteris Paribus.

\section{Pengarub spiritualitas terhadap kinerja dosen STAIN Salatiga}

Berdasarkan hasil uji t, peneliti mendapatkan variabel spiritualitas secara parsial mempunyai nilai t hitung -1,189 dengan probabilitas atau taraf signifikansi ( $p$ value) menunjukkan nilai sebesar 0,239 (signifikansi), di mana nilai probabilitas ini berada di atas atau lebih besar dari 0,05, sehingga dapat dikatakan bahwa secara parsial dalam penelitian ini spiritualitas secara statistik tidak berpengaruh secara signifikan terhadap kinerja para dosen.

\section{Pengarub intelektualitas terhadap kinerja dosen STAIN Salatiga}

Berdasarkan hasil uji t, peneliti mendapatkan variabel intelektualitas secara parsial mempunyai nilai t hitung 1,129 dengan probabilitas atau taraf signifikansi ( $p$ value) menunjukkan nilai sebesar 0,263 (signifikansi), di mana nilai probabilitas ini berada di atas atau lebih besar dari 0,05, sehingga dapat dikatakan bahwa secara parsial dalam penelitian ini intelektualitas secara statistik tidak berpengaruh secara signifikan terhadap kinerja para dosen.

\section{Pengarub profesionalisme terhadap kinerja dosen STAIN Salatiga}

Berdasarkan hasil uji t yang tersaji dalam tabel, peneliti mendapatkan variabel profesionalisme menunjukkan bahwa nilai $\mathrm{t}$ sebesar 8,931 dengan tingkat probabilitas atau taraf signifikansi ( $p$ value) menunjukkan nilai sebesar 0,000 (signifikansi). Karena probabilitas ( $p$ value) menunjukkan jauh lebih kecil dari 0,05 $(0,00<0,05)$, maka dapat dikatakan bahwa secara parsial dalam 
penelitian ini profesionaliseme secara statistik berpengaruh positif dan signifikan terhadap kinerja dosen. Hal ini berarti, semakin tinggi tingkat profesionalisme, maka semakin tinggi kinerja dosen. Hasil pengujian ini secara empiris menolak hipotesis null dan mendukung secara empiris hipotesis ketiga yang diajukan (H3) yang menyatakan bahwa profesionalisme berpengaruh positif terhadap kinerja

Tabel 3. Uji-F

\begin{tabular}{rlrrrrr}
\hline & Model & Sum of Squares & df & Mean Square & F & Sig. \\
\hline 1 & Regression & 852.736 & 3 & 284.245 & 44.561 & $.000^{a}$ \\
& Residual & 389.110 & 61 & 6.379 & & \\
Total & 1241.846 & 64 & & & \\
\hline
\end{tabular}

a. Predictors: (Constant), Prof, Intelek, Spirit

b. Dependent Variable: Kinerja

Berdasarkan hasil uji $\mathrm{F}$ test atau ANOVA pada di atas, peneliti mendapatkan nilai $\mathrm{F}$ hitung sebesar 44.561 dengan tingkat probabilitas 0.000 (signifikansi). Karena probabilitas jauh lebih kecil dari 0,05, maka model regresi dapat digunakan untuk memprediksi kinerja dosen atau dapat dikatakan bahwa spiritualitas, intelektualitas dan profesionalisme dosen secara bersama-sama berpengaruh terhadap kinerja dosen. Dengan demikian, hasil pengujian ini secara empiris menolak hipotesis null dan mendukung secara empiris hipotesis keempat yang diajukan (H4) yang menyatakan bahwa spiritualitas, intelektualitas dan profesionalisme secara bersama sama berpengaruh terhadap kinerja dosen.

\section{Koefisien Determinasi}

Pengujian ini untuk mengetahui seberapa jauh variasi variabel independen mampu menjelaskan variasi variabel dependen. Adapun hasilnya sebagaimana tercantum di tabel berikut: 
Tabel 4.Hasil Uji Determinasi

Model Summary

\begin{tabular}{llrrrr}
\hline Model & $\mathrm{R}$ & R Square & $\begin{array}{c}\text { Adjusted } \mathrm{R} \\
\text { Square }\end{array}$ & $\begin{array}{c}\text { Std. Error of the } \\
\text { Estimate }\end{array}$ \\
\hline 1 & $.829^{\mathrm{a}}$ & & .687 & .671 & 2.526 \\
\hline
\end{tabular}

a. Predictors: (Constant), Prof, Intelek, Spirit

Berdasarkan output SPSS tersebut di atas, besarnya Adjusted $R$ squared adalah 0.671 , yang berarti $67,1 \%$ variasi kinerja dapat dijelaskan oleh variasi dari ketiga variabel independen spiritualitas, intelektualitas dan profesionalisme. Sedangkan sisanya 32,9\% dijelaskan oleh sebab (faktor) lainnya di luar model.

Berdasarkan hasil penghitungan statistik di atas, hubungan masing-masing variabel menunjukkan hasil yang berbeda-beda. Spiritualitas tidak berpengaruh terhadap Kinerja secara statistik. Hal ini bertolak belakang dengan penelitian sebelumnya yang dilakukan Neck and Milliman (Sulistyo, 2011:132) yang menunjukkan bahwa organisasi yang kaya dengan nilai-nilai spiritualitas akan mendorong kinerja organisasi yang lebih baik.

Sementara itu, hasil uji statistik juga menunjukkan hasil yang berbeda dengan penelitian sebelumnya. Penelitian ini menunjukkan bahwa profesionalisme tidak berpengaruh secara signifikan dan positif. Ini berbeda dengan penelitian sebelumnya yang diajukan oleh Yasa (2013) yang dalam penelitiannya menyimpulkan bahwa independensi, profesionalisme, tingkat pendidikan dan pengalaman kerja berpengaruh positif dan signifikan terhadap kinerja auditor.

\section{Kesimpulan}

Berdasarkan hasil analisis yang telah diuraikan di atas, dapat diambil kesimpulan bahwa: peneliti mendapatkan variabel spiritualitas secara statistik tidak berpengaruh secara signifikan terhadap kinerja para dosen. Untuk variabel intelektualitas secara statistik tidak berpengaruh secara signifikan terhadap kinerja para dosen. Sedangkan profesionalisme secara statistik berpengaruh positif dan signifikan terhadap kinerja dosen. Sementara itu, Spiritualitas, intelektualitas 
dan profesionalisme dosen secara bersama-sama berpengaruh terhadap kinerja dosen.

\section{Daftar Pustaka}

Bawono, Anton. 2006. Multivariate Analysis, Salatiga: STAIN Salatiga Press.

Cahyasumirat, Gunawan. 2006. Pengaruh Profesionalisme dan Komitmen Organisasi terhadap Kinerja Internal Auditor dengan Kepuasan Kerja sebagai Variabel Intervening (Studi Empiris Pada Internal Auditor PT. BANK ABC). Tesis. Program Studi Magister Sains Akuntansi Program Pascasarjana Universitas Diponegoro. Semarang.

Irmim, Soejitno dan Abdul Rochim. 2006. Menuju Bisnis yang Islami. Seyma Media.

Karim, M. 2013. "Dinamika Islam Di Indonesia Suatu Tinjauan Sosial", dalam Sri Susanti. Kajian Kritis Terhadap Konsepsi "Ulil Albab" Dalam Al-Qur an, Jurnal Dimensi Pendidikan dan Pembelajaran, Volume 1, Nomor 1, Januari.

Neck, Christopher P, Milliman, John F. 1994. "Thought self-leadership: Finding spiritual fulfillment in organizational life". Journal of Managerial Psychology. Bradford. Vol. 9, Iss. 6.

Permana, Hilal Abraham. 2012.Pengarub Budaya Organisasi dan Motivasi SpiritualterhadapKinerjaKaryawan(studi pada PT. Delta Surya Textile Pasuruan). Skripsi, Jurusan Manajemen, Fakultas Ekonomi, Universitas Negeri Malang.

Rachman, Mochammad Munir. 2012. "Pengaruh kemampuan intelektual, pembelajaran individu dan internal locus of control pada kompetensi dan kinerja dosen" (Studi Prodi Manajemen Terakreditasi B Pada Universitas Swasta di Surabaya)". Majalah Ekonomi,Tahun XXII, No. 1 April.

Rahmat, Jalaluddin. 1991. Islam Alternatif. Bandung : Mizan.

Rahmawati. 1997. Hubungan antara Profesionalisme Internal Auditor dengan Kinerja, Kepuasan Kerja, Komitmen dan Keinginan Untuk Pindah. Tesis Program Pasca Sarjana UGM (Tidak dipublikasikan). 
Reker, G.T.. 2003. Provisional manual of the Spiritual Transcendence Scale (STS-24). Peterborough, ON: Student Psychologists Press.

Riduwan. 2005. Metode dan Teknik Menyusun Tesis, Cetakan Ketiga, Bandung : Alfabeta.

Rusman. 2011. Model-Model Pembelajaran. Jakarta: PT Raja Grafindo Persada.

Santosa, Setyarini. 2011. Pengarub Modal Intelektual dan Pengungkapannya terhadap Kinerja Perusahaan. Fakultas Ekonomi, Universitas Internasional Batam.

Sekaran,Uma. 2006, Research Methods For Business, Edisi 4, Buku 1, Jakarta: Salemba Empat.

Siahaan, Victor D. 2010. "Pengaruh Profesionalisme terhadap Komitmen Organisasi dalam Upaya Meningkatkan Kinerja Auditor (Studi pada Kantor Perwakilan BPK-RI Propinsi Aceh". Jurnal Telaah \& Riset Akuntansi, Vol. 3 No. 1

Stone, Raymond J. 2005. Human Resource Mana-gement, 5th ed. Sydney: John Wiley \& Sons.

Sulistiyo. 2011. "Agung Budi Peran Spiritualitas Keagamaan Bagi Akunta ndalam Lingkungan Organisasi". Jurnal Reviw Akuntansidan Keuangan, Vol.1 No. 2, Oktober.

Susanti. Sri. 2013. "Kajian Kritis Terhadap Konsepsi Ulil Albab Dalam Al-Qur an", Jurnal Dimensi Pendidikan dan Pembelajaran. Volume 1, Nomor 1, Januari

Swastha, Basu. 2000. Manajemen Pemasaran : Analisis Perilaku Konsumen, Yogyakarta: BPFE.

Tafsir, Ahmad. 1994. Ilmu Pendidikan dalam Perspektif Islam. Bandung: Remaja Rosda Karya.

Trihandini, R.A Fabiola Meirnayati, SPsi. 2005. Analisis Pengaruh Kecerdasan Intelektual, Kecerdasan Emosi dan Kecerdasan Spiritual terhadap Kinerja Karyawan (Studi Kasus di Hotel Horison Semarang). Tesis. Program Magister Manajemen Universitas Diponegoro Semarang.

Widyawati, Retno Febriyastuti, Arif Pujiyono. 2013. "Pengaruh Umur, Jumlah Tanggungan Keluarga, Luas Lahan, Pendidikan, Jarak Tempat Tinggal Pekerja ke Tempat Kerja, dan Keuntungan terhadap Curahan Waktu Kerja Wanita Tani Sektor Pertanian 
di Desa Tajuk, Kec. Getasan, Kab. Semarang”. Diponegoro Journal of Economics. Volume 2 Nomor 3.

Yamin, Martinis. 2009. Profesionalisasi Guru Dan Implementasi KTSP. Jakarta: Gaung Persada Press.

Yasa, I Gede Widya Saputra Gerianta Wirawan. 2013. "Pengaruh Independensi, Profesionalisme, Tingkat Pendidikan dan Pengalaman Kerja pada Kinerja Auditor BPK RI Perwakilan Provinsi Bali”. E-Jurnal Akuntansi Universitas Udayana. Vol 2, No, 2 Februari. 